CLINICAL STUDY

\title{
Long-term outcome in 46 gene carriers of hereditary medullary thyroid carcinoma after prophylactic thyroidectomy: impact of individual RET genotype
}

\author{
K Frank-Raue, H Buhr ${ }^{1}$, H Dralle ${ }^{2}$, E Klar ${ }^{3}$, N Senninger ${ }^{4}$, T Weber ${ }^{5}$, S Rondot, W Höppner ${ }^{6}$ and F Raue \\ Endokrinologische Gemeinschaftspraxis, 69120 Heidelberg, Germany, ${ }^{1}$ Chirurgische Universitätsklinik Charite, 12200 Berlin, Germany, ${ }^{2}$ Chirurgische \\ Universitätsklinik Halle, 06120 Halle, Germany, ${ }^{3}$ Chirurgische Universitätsklinik Rostock, 18057 Rostock, Germany, ${ }^{4}$ Chirurgische Universitätsklinik \\ Münster, 48149 Münster, Germany, ${ }^{5}$ Chirurgische Universitätsklinik Heidelberg, 69120 Heidelberg, Germany and ${ }^{6}$ Inst. für Hormon- und \\ Fertilitätsforschung, 22529 Hamburg, Germany
}

(Correspondence should be addressed to K Frank-Raue; Email: karin.frankraue@raue-endokrinologie.de)

\begin{abstract}
Objective: In children with RET proto-oncogene mutation, curative treatment of medullary thyroid carcinoma (MTC) is possible by prophylactic thyroidectomy. Recommendations on the timing and extent of thyroidectomy are based upon a model that utilises genotype-phenotype correlations to stratify mutations into three risk groups.

Design: We evaluated the long-term outcome (mean follow-up 6.4 years, 15 patients more than 10 years, 26 patients more than 5 years) of operated gene carriers stratified into two risk groups (levels 1 and 2) based on the biological aggressiveness of MTC.

Results: In 46 RET gene carriers, prophylactic thyroidectomy was carried out between the ages of 4 and 21 years. Level 1 mutations were harboured by 11 patients (codons 790, 791, 804 and 891). Histology was completely normal in two patients; in seven patients C-cell hyperplasia $(\mathrm{CCH})$ and in two patients T1 tumours were diagnosed. All patients with level 1 mutations were cured. Level 2 mutations were harboured by 35 patients (codons 618, 620, 630 and 634). Histology of these patients showed $\mathrm{CCH}$ in 11 patients, T1 tumours in 21, T2 tumour in 1, T3 tumour in 1 and Tx in 1 patient. Histology showed no lymph node involvement. Five patients with level 2 mutations failed to be cured; in two patients, persistence of MTC was diagnosed directly after thyroidectomy and in three during follow-up. In two patients carrying a 634 mutation, other endocrinopathies (hyperparathyroidism and bilateral pheochromocytoma) manifested during follow-up.

Conclusions: If prophylactic thyroidectomy is done at early ages, cure rate is high. Timing and extent of prophylactic thyroidectomy can be modified by individual RET mutation.
\end{abstract}

European Journal of Endocrinology 155 229-236

\section{Introduction}

Missense germline mutations in the RET proto-oncogene are associated with multiple endocrine neoplasia type-2A (MEN 2A) and familial medullary thyroid carcinoma (FMTC) $(1,2)$. Detection of the mutant alleles in kindred members predicts disease inheritance and provides the basis for prophylactic thyroidectomy in children (3-5). If properly used, DNA analysis is highly accurate and reproducible. Early total thyroidectomy can prevent MTC with persistent or recurrent disease (6). There is a significant age-related progression from C-cell hyperplasia $(\mathrm{CCH})$ to medullary thyroid carcinoma (MTC) correlating with the transforming potential of the respective RET mutations (7). Codonspecific prognosis would allow individualised risk stratification for each patient (8). Recommendations on the timing of prophylactic thyroidectomy and the extent of surgery are based upon a model that utilises genotype-phenotype correlations to stratify mutations into three risk levels (9-13). Patients with level 1 mutations (codons 609, 768, 790, 791, 804 and 891) have the lowest risk of the development and growth of MTC. Patients with level 2 mutations (codons 611, 618, 620 and 634) are at intermediate risk, and patients with level 3 mutations (codons 883 and 918) are at the highest risk of the early development and growth of MTC. Postoperative lifelong thyroxine-replacement therapy has to be done in order to achieve normal growth, development and intellectual function with normal T4 and thyrotrophin (TSH) concentrations. In this present study, we examined 46 members of 28 MEN 2A/FMTC families younger than 21 years, who were evaluated by DNA analysis and biochemical testing and then underwent prophylactic thyroidectomy. Results of preoperative calcitonin levels, histological examination, 
cure rate and postoperative long-term follow-up are analysed and stratified by the risk level of the individual RET genotype.

\section{Materials and methods}

Between 1986 and 1992, the era before the identification of the RET gene, ten members of eight MEN 2A/FMTC families had thyroidectomy on the basis of pentagastrin (PG) testing between the ages of 6 and 17 years (mean 13.0 years). Since 1993, we have studied 36 members of 20 MEN 2A/FMTC families, who underwent prophylactic thyroidectomy between the ages 4 and 21 years (mean 11.2 years) based on genetic testing. All patients were seen by two of the authors (K F-R, F R) during the last 20 years. Informed consent was obtained from the patients or their parents. The studies involved a medical history, physical examination and measurements of basal and stimulated serum calcitonin concentrations, TSH and free thyroxine (FT4) as well as DNA analysis since 1993. Calcitonin measurement was done by chemiluminescence assay (Nichols Institute, Bad Vilbel, Germany). The normal basal levels and for males were $<10.3 \mathrm{pg} / \mathrm{ml}$, and for females $<4.3 \mathrm{pg} / \mathrm{ml}$. After total thyroidectomy, no increase in calcitonin after $\mathrm{PG}(0.5 \mu \mathrm{g} / \mathrm{kg}$ body weight i.v. $)$ was considered normal. TSH and FT4 were estimated using an automated chemiluminescence system (Bayer), reference range: TSH $0.35-4.5 \mu \mathrm{U} / \mathrm{ml}$; FT4 $0.8-$ $1.7 \mathrm{ng} / \mathrm{dl}$. Mutation analysis of the RET proto-oncogene: genomic DNA was extracted from peripheral leukocytes and exons 10, 11 and 13, 14 and 15 of the RET gene were amplified by PCR using specific oligonucleotide primers $(14,15)$. Twelve different surgeons/surgical centres performed a total thyroidectomy, 24 patients were operated on by two of the authors (H B, H D). Lymph nodes in the central zone of the neck were resected in 34 of the 46 patients, since 2001 concerning the guidelines of the MEN consortium (9). Tumour staging was performed according to the International Union against Cancer tumour node metastasis classification from 1997. Postoperatively, a PG test, serum calcium and parathyroid hormone levels, and catecholamines were checked and thyroxine substitution was started. In the follow-up, children were examined once a year in our centre and, as recommended, every 3 months by the paediatrician or general practitioner concerning thyroxine substitution. Mean follow-up time was 6.4 years, (median 7.5 years; range $0.1-14$ years), 15 patients were followed more than 10 years, 26 patients for more than 5 years.

\section{Statistical analysis}

Statistical analysis included Mann-Whitney rank sum test and two-tailed Fisher's exact test as appropriate. The results are expressed as the mean \pm s.D. $P<0.05$ was considered significant.

\section{Results}

Forty-six presymptomatic gene carriers out of 28 families with mutations in the RET proto-oncogene had prophylactic thyroidectomy. The patients were stratified into two groups based on the biological aggressiveness of MTC as suggested by others $(9,13)$ (Table 1).

\section{Level 1 mutations}

Six families (11 patients) harboured level 1 mutations (Tables 1 and 2). In two families, the mutations were in codon 790 , in one family in codon 791 , in one in codon 804 and in two families in codon 891. Mean age at prophylactic thyroidectomy in these 11 patients was $11.8 \pm 5.7$ years (range 4-21 years). Histology was completely normal without CCH or MTC in two patients carrying L790F mutations. In seven patients, $\mathrm{CCH}$ was documented and T1 tumours were diagnosed in two out of the 11 patients. No patient had lymph node involvement. All patients with level 1 mutations were cured. In one patient (no. 6) carrying a V804M mutation, basal calcitonin level was slightly elevated postoperatively, but there was no increase after PG stimulation; histology showed $\mathrm{CCH}$ only, therefore, we suspect non-MTC causes of calcitonin elevation. In the patients with level 1 mutations, preoperative basal calcitonin levels were elevated in six out of the ten patients (mean $13.5 \pm 7.2 \mathrm{pg} / \mathrm{ml}$ ); after PG stimulation, calcitonin increased in all tests (mean $97.3 \pm 156.7 \mathrm{pg}$ / $\mathrm{ml}$ ). Even in the two patients with normal histology (no CCH, no MTC; patients nos 3 and 4), calcitonin increased to 41 and $49 \mathrm{pg} / \mathrm{ml}$ respectively (Tables 2 and 4). In patients with level 1 mutations, the one patient with a T1 tumour (patient no. 11) showed the highest stimulated calcitonin value.

\section{Level 2 mutations}

Twenty-two families harboured level 2 mutations: 18 in exon 11 codon 634, one in codon 630 (16), two families in exon 10 codon 618 and one in 620. Mean age at operation in these 35 patients was $11.1 \pm 4.3$ years (range 4-18 years). Histology of these patients showed $\mathrm{CCH}$ in 11 patients, $\mathrm{T} 1$ tumours in 21 and $\mathrm{T} 2$ tumour in one, T3 tumour in one and Tx in one patient. The histologic results after the first surgery showed no lymph node involvement. Five out of 35 patients with level 2 mutations failed to be cured (Table 3). In two of them, the first PG test after thyroidectomy showed a pathological increase, in three patients PG test results converted during follow-up (12, 13 and 13 years postoperatively) from normal to pathological results. Clinical disease manifestation (palpation, ultrasound and computerised tomography) could not be demonstrated in any of these patients. Two patients with persistently elevated calcitonin had a second operation 
Table 1 Patients characteristics stratified by risk groups concerning RET mutation.

\begin{tabular}{|c|c|c|c|}
\hline & Level 1 & Level 2 & $P$ values \\
\hline Number of patients & 11 & 35 & \\
\hline Age at diagnosis, $x \pm$ s.D. years (range) & $11.8 \pm 5.7(4-21)$ & $11.1 \pm 4.3(4-18)$ & n.s. \\
\hline Number of families & 6 & 22 & \\
\hline Codon/number of patients & $790 / 4,791 / 1,804 / 1,891 / 5$ & $634 / 31,630 / 1,620 / 1,618 / 2$ & \\
\hline \multicolumn{4}{|l|}{ Histology } \\
\hline Normal & 2 & 0 & \multirow{6}{*}{0.028} \\
\hline $\mathrm{CCH}$ & 7 & 11 & \\
\hline MTC T1 & 2 & 21 & \\
\hline MTC T2 & - & 1 & \\
\hline MTC T3 & - & 1 & \\
\hline MTC Tx & - & 1 & \\
\hline \multicolumn{4}{|c|}{ Calcitonin (pg/ml), $x \pm$ s.D. (range) preoperatively } \\
\hline Basal, all & $13.5 \pm 7.2(5-24)$ & $54.7 \pm 66.1(6-351)$ & 0.002 \\
\hline After PG, all & $97.3 \pm 156.7(12-510)$ & $447.3 \pm 413.3(62-1550)$ & 0.001 \\
\hline Basal, $\mathrm{CCH}$ only & $13.5 \pm 6.8(7-23)$ & $28.2 \pm 11.9(12-49)$ & 0.014 \\
\hline After PG, CCH only & $46 \pm 31.5(12-100)$ & $312.4 \pm 251.6(66-807)$ & 0.003 \\
\hline Number of patients cured & 11 & 30 & \multirow{2}{*}{ n.s. } \\
\hline Number of patients not cured & - & 5 & \\
\hline
\end{tabular}

MTC, medullary thyroid carcinoma; $\mathrm{CCH}, \mathrm{C}$-cell hyperplasia; PG, pentagastrin.

during follow-up, in one patient (no. 15) lateral lymph node dissection was done, but no tumour tissue could be removed, in patient no. 13, one micro lymph node metastasis in the lateral compartment was diagnosed. In both cases, calcitonin levels were persistently elevated after PG stimulation. Preoperative basal calcitonin levels were elevated in 31 out of 32 patients (mean $54.7 \pm 66.1 \mathrm{pg} / \mathrm{ml}$; range $6-351 \mathrm{pg} / \mathrm{ml}$ ) (Table 4). After PG stimulation, calcitonin increased in all the available PG tests $(447.3 \pm 413.3 \mathrm{pg} / \mathrm{ml}$; range $62-1550 \mathrm{pg} / \mathrm{ml}$ ). Among the three patients with calcitonin increase above $1000 \mathrm{pg} / \mathrm{ml}$ after preoperative PG stimulation, in two patients curative thyroidectomy was not possible. In patients with level 2 mutations, preoperative basal as well as stimulated calcitonin levels increased with the tumour stage. In patients with $\mathrm{CCH}$, mean basal/PG-stimulated calcitonin levels were $28.2 \pm 11.9 / 312.4 \pm 251.6 \mathrm{pg} / \mathrm{ml}$, and in patients with T1 tumours, $54.2 \pm 46.3 / 541.2 \pm 477.2 \mathrm{pg} / \mathrm{ml}$; this result failed to reach statistical significance. Again, in patients with level 2 mutations, the patient with the advanced tumour stage (T2, patient no. 43) had the highest basal calcitonin value (Table 4).

\section{Comparison between patients carrying level 1 or level 2 RET mutations (Tables 1 and 4)}

In our patient groups harbouring RET level 1 or level 2 mutations, there was no significant difference concerning age at thyroidectomy. Preoperative basal and PG-stimulated calcitonin levels were significantly different in patients carrying level 1 or level 2 mutations $(13.5 \pm 7.2 / 97.3 \pm 156.7$ vs $54.7 \pm 66.1 / 447.3 \pm$ $413.3 \mathrm{pg} / \mathrm{ml}$; basal calcitonin $P=0.002$; calcitonin after PG $P=0.001)$. Harbouring a level 1 mutation

Table 2 Patients with level 1 risk group.

\begin{tabular}{|c|c|c|c|c|c|c|c|}
\hline Patient no. & $\begin{array}{l}\text { RET } \\
\text { mutation }\end{array}$ & Sex & $\begin{array}{c}\text { Age at } \\
\text { OP year }\end{array}$ & $\begin{array}{l}\text { Calcitonin } \\
\text { preoperative } \\
\text { basal/PG (pg/ml) }\end{array}$ & $\begin{array}{l}\text { Tumour stage/ } \\
\text { histology }\end{array}$ & $\begin{array}{c}\text { Calcitonin } \\
\text { postoperative } \\
\text { basal/PG (pg/ml) }\end{array}$ & Cured \\
\hline 1 & L790F & $\mathrm{F}$ & 16 & $-1-$ & $\mathrm{T} 1 \mathrm{Nx}$ & $<0.2 /<0.2$ & Yes \\
\hline 2 & L790F & $M$ & 19 & $23 / 100$ & $\mathrm{CCH}, \mathrm{TONx}$ & $<0.2 /<0.2$ & Yes \\
\hline 3 & L790F & $\mathrm{M}$ & 13 & $11 / 41$ & No CCH, TONx & $<0.2 /<0.2$ & Yes \\
\hline 4 & L790F & $\mathrm{M}$ & 21 & $5 / 49$ & No $\mathrm{CCH}$, TONx & $<0.2 /<0.2$ & Yes \\
\hline 5 & Y791F & $\mathrm{M}$ & 10 & $8 / 32$ & $\mathrm{CCH}, \mathrm{TONO}$ & $<0.2 /<0.2$ & Yes \\
\hline 6 & V804M & $\mathrm{M}$ & 6 & $23 /-$ & $\mathrm{CCH}, \mathrm{TONO}$ & $15 / 16$ & ? Yes \\
\hline 7 & S891A & $\mathrm{F}$ & 4 & $11 / 23$ & $\mathrm{CCH}, \mathrm{TONx}$ & $-1-$ & Yes \\
\hline 8 & S891A & $\mathrm{F}$ & 10 & $14 / 52$ & $\mathrm{CCH}, \mathrm{TONx}$ & $<0.2 /<0.2$ & Yes \\
\hline 9 & S891A & $\mathrm{M}$ & 8 & 6.6/12 & $\mathrm{CCH}, \mathrm{TONx}$ & $<0.2 /-$ & Yes \\
\hline 10 & S891A & $\mathrm{M}$ & 6 & $8.6 / 57$ & $\mathrm{CCH}, \mathrm{TONx}$ & $<0.2 /<0,2$ & Yes \\
\hline 11 & S891A & $\mathrm{M}$ & 17 & $24 / 510$ & T1No & $0.2 / 2$ & Yes \\
\hline
\end{tabular}

$\mathrm{CCH}, \mathrm{C}$-cell hyperplasia; PG, pentagastrin. 
Table 3 Patients with persistent or recurrent disease after thyroidectomy.

\begin{tabular}{|c|c|c|c|c|c|c|c|c|c|c|}
\hline $\begin{array}{l}\text { Patient } \\
\text { no. }\end{array}$ & Level & $\begin{array}{c}R E T \\
\text { mutation }\end{array}$ & Sex & $\begin{array}{l}\text { Age at } \\
\text { surgery }\end{array}$ & $\begin{array}{c}\text { Calcitonin } \\
\text { pre oper- } \\
\text { ative } \\
\text { basal/PG } \\
(\mathrm{pg} / \mathrm{ml})\end{array}$ & $\begin{array}{l}\text { Patho- } \\
\text { logical } \\
\text { findings }\end{array}$ & $\begin{array}{c}\text { Calcitonin } \\
\text { postopera- } \\
\text { tive } \\
\text { basal/PG } \\
(\mathrm{pg} / \mathrm{ml})\end{array}$ & $\begin{array}{c}\text { Calcitonin } \\
\text { follow-up } \\
\text { basal/PG } \\
(\mathrm{pg} / \mathrm{ml})\end{array}$ & $\begin{array}{l}\text { Duration of } \\
\text { follow-up } \\
\text { (years) }\end{array}$ & Converter \\
\hline 12 & 2 & C620Y & $\mathrm{F}$ & 18 & $148 / 1550$ & T1No & $<2 /<2$ & $10 / 676$ & 12 & Yes \\
\hline 13 & 2 & C630R & $\mathrm{F}$ & 15 & $133 / 1110$ & $\mathrm{~T} 1 \mathrm{~N} 0 / \mathrm{N} 1^{\mathrm{a}}$ & $14 / 47$ & $<0.2 / 6$ & 10 & No \\
\hline 14 & 2 & C634R & $\mathrm{F}$ & 15 & $-1-$ & T3NO & $<0.1 /<0.1$ & $132 /-$ & 3 & Yes \\
\hline 15 & 2 & C634Y & $\mathrm{F}$ & 16 & $44 / 547$ & $\mathrm{CCH} \mathrm{NO}$ & $<2 /<2$ & $6 / 249$ & 13 & Yes \\
\hline 16 & 2 & C634Y & $\mathrm{F}$ & 13 & $37 / 287$ & T1No & $0.8 / 21$ & $-1-$ & 1 & No \\
\hline
\end{tabular}

$\mathrm{PG}$, pentagastrin; $\mathrm{CCH}, \mathrm{C}$-cell hyperplasia.

a'Lymph node metastasis left lateral compartment 6 years 5 months after initial surgery.

Table 4 Preoperative basal (CTb) and stimulated (CTs) calcitonin levels and their correlation to thyroid histology in levels 1 and 2 RET mutations.

\begin{tabular}{|c|c|c|c|c|c|}
\hline Patient no. & $R E T$ mutation & Sex & Histology & CTb (pg/ml) & CTs $(\mathrm{pg} / \mathrm{ml})$ \\
\hline \multicolumn{6}{|l|}{ Level 1} \\
\hline 3 & L790F & M & No $\mathrm{CCH}$ & 11 & 41 \\
\hline 4 & L790F & $\mathrm{M}$ & No $\mathrm{CCH}$ & 5 & 49 \\
\hline 2 & L790F & M & $\mathrm{CCH}$ & 23 & 100 \\
\hline 5 & Y791F & $\mathrm{M}$ & $\mathrm{CCH}$ & 8 & 32 \\
\hline 6 & V804M & M & $\mathrm{CCH}$ & 23 & - \\
\hline 7 & S891A & $\mathrm{F}$ & $\mathrm{CCH}$ & 11 & 23 \\
\hline 8 & S891A & $\mathrm{F}$ & $\mathrm{CCH}$ & 14 & 52 \\
\hline 9 & S891A & M & $\mathrm{CCH}$ & 6.6 & 12 \\
\hline 10 & S891A & M & $\mathrm{CCH}$ & 8.6 & 57 \\
\hline 11 & S891A & M & $\mathrm{T} 1$ & 24 & 510 \\
\hline \multicolumn{6}{|l|}{ Level 2} \\
\hline 17 & C634W & $\mathrm{F}$ & $\mathrm{CCH}$ & 15 & 807 \\
\hline 15 & C634Y & $\mathrm{F}$ & $\mathrm{CCH}$ & 44 & 547 \\
\hline 18 & C634R & M & $\mathrm{CCH}$ & 25 & 165 \\
\hline 19 & C634Y & $\mathrm{F}$ & $\mathrm{CCH}$ & 34 & 192 \\
\hline 20 & C634G & $\mathrm{F}$ & $\mathrm{CCH}$ & 21 & 472 \\
\hline 21 & $\mathrm{C} 634 \mathrm{Y}$ & $\mathrm{F}$ & $\mathrm{CCH}$ & 35 & 66 \\
\hline 22 & C634Y & M & $\mathrm{CCH}$ & 34 & 500 \\
\hline 23 & C634W & M & $\mathrm{CCH}$ & 21 & 111 \\
\hline 24 & C634Y & $\mathrm{F}$ & $\mathrm{CCH}$ & 20 & 190 \\
\hline 25 & C618S & $\mathrm{F}$ & $\mathrm{CCH}$ & 12 & 74 \\
\hline 26 & C634Y & $\mathrm{F}$ & $\mathrm{CCH}$ & 49 & - \\
\hline 27 & C634Y & $\mathrm{F}$ & $\mathrm{T} 1$ & 70 & 1200 \\
\hline 28 & C634R & M & $\mathrm{T} 1$ & 14 & 271 \\
\hline 29 & C634R & M & $\mathrm{T} 1$ & 6 & 308 \\
\hline 30 & C634G & $\mathrm{F}$ & $\mathrm{T} 1$ & 33 & 102 \\
\hline 31 & C634R & $\mathrm{F}$ & $\mathrm{T} 1$ & 37 & 691 \\
\hline 32 & C634W & M & $\mathrm{T} 1$ & 44 & 725 \\
\hline 16 & C634Y & $\mathrm{F}$ & $\mathrm{T} 1$ & 37 & 287 \\
\hline 33 & C634Y & $\mathrm{F}$ & $\mathrm{T} 1$ & 36 & - \\
\hline 34 & $\mathrm{C} 634 \mathrm{Y}$ & M & $\mathrm{T} 1$ & 44 & - \\
\hline 35 & C634Y & $\mathrm{F}$ & $\mathrm{T} 1$ & 7 & - \\
\hline 36 & C634W & $\mathrm{F}$ & $\mathrm{T} 1$ & 9 & 62 \\
\hline 37 & C634G & M & $\mathrm{T} 1$ & 101 & 319 \\
\hline 38 & C634R & $\mathrm{F}$ & $\mathrm{T} 1$ & 7 & - \\
\hline 39 & C634Y & M & $\mathrm{T} 1$ & 37 & 130 \\
\hline 40 & C634G & $\mathrm{F}$ & $\mathrm{T} 1$ & 33 & - \\
\hline 41 & C618S & $\mathrm{F}$ & $\mathrm{T} 1$ & 100 & 280 \\
\hline 12 & C620Y & $\mathrm{F}$ & $\mathrm{T} 1$ & 148 & 1550 \\
\hline 13 & C630R & $\mathrm{F}$ & $\mathrm{T} 1$ & 133 & 1110 \\
\hline 42 & C634Y & M & $\mathrm{T} 1$ & 133 & - \\
\hline 43 & C634Y & $\mathrm{F}$ & T2 & 351 & - \\
\hline 44 & C634Y & $\mathrm{F}$ & $T x$ & 59 & - \\
\hline
\end{tabular}


was significantly associated with the likelihood of having $\mathrm{CCH}$ rather than a $\mathrm{T} 1$ tumour when being operated on at the same age of about 11 years $(P=0.028)$. There was also a significant difference in the preoperative basal/stimulated calcitonin values between patients with $\mathrm{CCH}$ only carrying level 1 or level 2 mutations despite being operated on at the same age (13.5 \pm $6.8 / 46 \pm 31.5$ vs $28.2 \pm 11.9 / 312.4 \pm 251.6 \mathrm{pg} / \mathrm{ml}$; basal calcitonin $P=0.014$; calcitonin after $P G P=$ 0.003). Despite the fact that all patients with level 1 mutations were cured, compared with only 31 of the 36 carrying level 2 mutations, this result failed to reach statistical significance.

\section{Other endocrinopathies}

In two patients carrying a 634 mutation, endocrinopathies other than MTC manifested during follow-up. A 12-year-old boy (C634R) developed hyperparathyroidism 5 years after thyroidectomy and a 28-year-old woman (C634Y) had bilateral adrenalectomy because of pheochromocytomas 12 years after thyroidectomy.

\section{Risks of surgery}

There was no recurrent laryngeal nerve damage. In one patient, permanent postoperative hypoparathyroidism was obvious.

\section{Postoperative management}

All patients received thyroxine doses between 50 and $175 \mu \mathrm{g}$ postoperatively depending on their age and TSH level. During follow-up under thyroxine substitution therapy in many patients TSH was elevated: after 1 year in $31 \%$ of patients (mean $11.1 \pm 29.2 \mu \mathrm{U} / \mathrm{ml}$; median $0.5 \mu \mathrm{U} / \mathrm{ml}$; range $0.01-147 \mu \mathrm{U} / \mathrm{ml}$ ), and in $26 \% \mathrm{TSH}$ levels were elevated after 5 years (mean $4.04 \pm$ $6.4 \mu \mathrm{U} / \mathrm{ml}$; median $0.8 \mu \mathrm{U} / \mathrm{ml}$; range $0.01-24 \mu \mathrm{U} / \mathrm{ml}$ ). Only in three patients was FT4 decreased (once $<0.4$ and 2 times $0.7 \mathrm{ng} / \mathrm{dl}$ ); these patients had TSH above $50 \mu \mathrm{U} / \mathrm{ml}$; in others, despite TSH values between 69 and $108 \mu \mathrm{U} / \mathrm{ml}$, FT4 was in the normal range. No symptoms of hypothyroidism, such as being more tired, feeling colder, having more constipation or impaired school performance, were reported; no reduction of growth velocity was documented.

\section{Discussion}

We report long-term follow-up and outcome data of children and adolescents after prophylactic thyroidectomy harbouring mutations in the RET protooncogene. Initially, 44 out of 46 patients seemed to be cured; two had persistently elevated calcitonin levels and three patients converted from normal to pathological PG test during follow-up. Patients with elevated calcitonin levels postoperatively were considered to have residual MTC. In 41 out of 46 patients, MTC could be prevented or cured by total thyroidectomy. These results are in line with another recently published study, where 44 out of 50 patients after prophylactic thyroidectomy showed normal calcitonin levels 5-10 years after operation (6). Factors affecting outcome are; age at the time of thyroidectomy, the histological status of the operated thyroid and the tumour stage, the preoperative calcitonin level and the specific RET codon mutation. Recent data confirmed that the biological behaviour of MTC can be stratified by the specific RET mutation in a MEN 2 population. RET mutations have been divided into three risk groups (levels 1-3) $(9,13,17)$. Patients with level 1 mutations have a high risk for the development and growth of MTC, but the age at the onset and the aggressiveness of MTC vary considerably. Since patients with level 1 mutations develop MTC with less aggressive metastatic potential and also have an initial delay in the neoplastic transformation of the C-cells, there is no consensus on the timing of thyroidectomy in these patients. Patients with level 2 mutations have a higher risk for early development and growth of MTC. There is a significant age-related progression from $\mathrm{CCH}$ to MTC clearly demonstrated in carriers of 634 RET mutation (7) and invasive MTC may be present as early as 5 years (13). Current guidelines for the treatment of patients with level 2 mutations recommend total thyroidectomy by the age of 5 years.

Mean age at operation in our patients with level 1 and level 2 RET mutations did not differ. Although same age, only 30 of 35 patients with level 2 mutations were cured, while all patients with level 1 mutation showed normal plasma calcitonin in the follow-up. This difference in the biological behaviour is also demonstrated by the significant difference in the preoperative basal/stimulated calcitonin values between patients with CCH only carrying level 1 or level 2 RET mutations despite being operated at the same age. All of our patients who were not cured carried level 2 mutations, and were operated on before 1997 and after the age of 13 years. Regarding the current guidelines published in 2001, thyroidectomy in our patients with level 2 mutations was performed too late; only in three patients was thyroidectomy performed before or at the age of 5 years, in four patients it was performed at the age of 6 years. In all the patients with level 2 mutations who failed to be cured, thyroidectomy was performed between the ages of 13 and 18 years. The reasons for the relatively late operation in our series are the late diagnosis provided by biochemical screening before 1993 in ten patients, the old age in some patients in the first family work-up and in some families a timeconsuming decision-making process; additionally, the lacking consensus about the optimal time for operation until the first guideline was published (2001) may have influenced the time of therapy (9). Despite this late 
operation, most patients were cured; only in two patients harbouring 634 mutations were T2 and T3 tumours found. The girl with the T3 tumour was operated on at the age of 15 years and primarily thought to be cured, but during follow-up PG test, she converted to pathological calcitonin levels. The girl with the T2 MTC was cured. In our series, five patients were not cured (Table 3); two of them had pathological PG test directly after prophylactic thyroidectomy and three patients converted during follow-up. One reason for conversion in two patients may be the older insensitive calcitonin assay used before 1991 since conversion occurred at the time of using the actual assay. All five of these patients had additional central lymphadenectomy at primary operation, but no tumour tissue in the central lymph nodes has been documented. There is an age-related progression in MTC tumour stage as well as an increase in preoperative calcitonin levels corresponding to tumour stage in level 2 mutations. The youngest patient with MTC was 5 at tumour stage T1, 13 at tumour stage T2 and 15 years at tumour stage T3. Preoperative basal as well as PG-stimulated calcitonin levels in patients with $\mathrm{CCH}$ are lower than in patients with MTC. Patients with persistent or recurrent MTC had the highest preoperative calcitonin levels, but there is a great overlap. Basal and PG-stimulated calcitonin levels, however, did not reliably discriminate between $\mathrm{CCH}$ and MTC and should therefore not be the only criterion used to define the timing of thyroid surgery.

All our patients carrying level 1 RET mutations (codons 790, 791, 804 and 891) are cured despite being operated on at a mean age of 11.8 years (Table 1). Also tumour stage and preoperative calcitonin levels were lower than in level 2 mutations; most patients had $\mathrm{CCH}$. In two patients operated on at the age of 13 and 21 years, not even a $\mathrm{CCH}$ was found. Both carry 790 mutations (level 1), known to induce mild MTC phenotypes $(8,12,15,18)$. In our series, harbouring a level 1 mutation is significantly associated with the likelihood of having $\mathrm{CCH}$ rather than a $\mathrm{T} 1$ tumour when being operated on at the same age of about 11 years. The aggressiveness and penetrance of MTC in level 1 mutations seem to be lower and patients may develop MTC at higher age (11). The optimal timing for surgery in these patients remains controversial. Plasma calcitonin cannot clearly differentiate between $\mathrm{CCH}$ and MTC and patients may develop lymph node metastases or distant metastases. Anecdotal patients with distant metastases at a young age and level 1 mutations are reported (19), showing the heterogeneity in biological behaviour within the same codon mutation. The observed inter- and intrafamilial phenotypic variability among patients carrying the same RET mutation suggests a role of genetic modifiers such as different polymorphisms. Although conflicting results exist, there are some interesting results: in FMTC patients, the F791Y mutation was found to be associated with the L769L polymorphism, suggesting a possible role as a genetic modifier (20). Recently, it has been reported that G691S and S904S polymorphisms may have a modifying effect on the age of onset of MEN $2 \mathrm{~A}$ (21), but this could not be replicated in a larger series (22). In this larger series of four different European populations, only RET A432A showed a positive weak effect on tumour spectrum within MEN 2A (22). Other studies revealed no associations of different RET polymorphisms to a specific mutation or to the clinical presentation (23).

Until now we have had to balance the risk of early metastasis and the small risk and sequelae of surgery in young children against the biological behaviour of MTC in other family members. There is good evidence for a decision concerning thyroidectomy in patients carrying level 2 mutations before the age of 6 years, especially for a mutation in RET codon $634(7,9)$, but decision for thyroidectomy in level 1 mutation carriers depends on personal experience and has to be individualised until more data are available. The results of our study support the relevance of treatment according to the guidelines stratifying management of MTC according to genetic information, and strengthen the requirement of further collaboration in data collection on gene carriers, especially of the less common RET mutations.

Insufficient postoperative thyroxine substitution, which is demonstrated in some of our patients, may impair normal growth, development and intellectual function. The 1- and 5-year TSH levels show that a relevant number of patients had no sufficient thyroid hormone substitution. One reason for the problems with thyroxine substitution may be lack of symptoms with mild- or short-term hypothyroidism. In most cases of TSH elevation, FT4 was in the normal range. This is inline with the observation of lacking clinical manifestations or developmental retardation. In the Colorado thyroid disease prevalence study (24) among patients taking thyroid medication, only $60 \%$ were within the normal range of TSH. The magnitude of elevation of TSH is commonly believed to correspond to the severity of tissue hypothyroidism. When evaluating thyroid hormone action at the tissue level, Meier and colleges (25) found good correlations with both circulating hormones but no, or only weak, correlations with serum TSH. This may be one of the explanations for the absence of clinical signs and symptoms of hypothyroidism in our patients. In some patients, TSH concentration remains high despite a thyroxine dose that should be adequate. After excluding conditions that increase the need for thyroxine (e.g. drugs), poor compliance (patient and/or parental noncompliance) is the most common reason for this finding and should be suspected in patients receiving adequate doses of thyroxine for their age, or in those with varying TSH levels while taking the same prescribed dose. The consequence of these problems should not be to delay surgery, because of increased risk of advanced MTC with lymph node metastases. 
Therefore, the children and the parents must understand the necessity for daily thyroxine therapy, if their child is to grow and develop normally. Intensive followup, with TSH monitoring (e.g. every 3 months or shorter) and dose adjustment, as long as TSH is not in the normal range, has to be done.

\section{Conclusion}

The application of genetic testing in hereditary MTC is safe concerning diagnostic accuracy. This study confirmed that the biologic behaviour of MTC can be stratified by the specific RET mutations in a MEN2 population. These results and the long-term follow-up data support the relevance of treatment according the guidelines stratifying management of MTC according to genetic information in levels 1-2. Our results also strengthen the requirement of further collaboration in data collection on gene carriers of the less common RET mutations before a codon-specific recommendation for prophylactic thyroidectomy is possible. If prophylactic thyroidectomy is done at an early age, the cure rate will be $100 \%$, and will improve significantly the long-term outcome and prognosis of these patients. Despite these encouraging results, thyroxine-substitution therapy in the follow-up carries some problems concerning optimal dosage and non-compliance. Therefore, TSH has to be estimated in these young patients during follow-up every 3 months.

\section{Acknowledgements}

Most of the operations have been performed in three different institutions (Chirurgische Universitätsklinik Heidelberg by H Buhr, E Klar, N Senninger, T Weber, M W Büchler, Chirurgische Universität Halle by $\mathrm{H}$ Dralle, and Charite, Berlin by H Buhr)

Part of this has been presented at the 22nd annual meeting of the surgical working group of endocrine surgery (CAEK), December 2003, Germany and at the meeting of the German Endocrine Society, March 2005, Germany.

\section{References}

1 Mulligan LM, Kwok JBJ, Healey CS, Elsdon MJ, Eng C, Gardner E, Love DR, Mole SE, Moore JK, Papi L, Ponder MA, Telenius H, Tunnacliffe A \& Ponder BAJ. Germ-line mutations of the RET protooncogene in multiple endocrine neoplasia type 2a (MEN 2A). Nature $1993363458-469$.

2 Donis-Keller H, Dou S, Chi D, Carlson KM, Toshiama K, Lairmore TG, Howe JR, Moley JF, Goodfellow P \& Wells SA, Jr. Mutations in the RET proto-oncogene are associated with MEN 2A and FMTC. Human Molecular Genetics 19932 851-856.

3 Wells SA, Chi DD, Toshima K, Dehner LP, Coffin CM, Dowton SB, Ivanovich JL, DeBenedetti MK, Dilley WG, Moley JF, Norton JA \&
Donis-Keller H. Predictive DNA testing and prophylactic thyroidectomy in patients at risk for multiple endocrine neoplasia type 2a. Annals of Surgery 1994220 237-250.

4 Dralle H, Grimm O, Simon D, Frank-Raue K, Görtz G, Niederle B, Wahl RA, Koch B, Walgenbach S, Hampel R, Ritter MM, Spelsberg F, Heiß A, Hinze P \& Höppner W. Prophylactic thyroidectomy in 75 children and adolescents with hereditary medullary thyroid carcinoma: German and Austrian experience. World Journal of Surgery 199722 744-751.

5 Niccoli-Sire P, Murat A, Baudin E, Henry JF, Proye C, Bigorgne JC, Bstandig B, Modigliani E, Morange S, Schlumberger M, ConteDevolx B \& The French Calcitonin Tumours Study Group (GETC). Early or prophylactic thyroidectomy in MEN 2/FMTC gene carriers: results of 71 thyroidectomized patients. European Journal of Endocrinology 1999141 468-474.

6 Skinner MA, Moley JA, Dilley WG, Owzar K, DeBenedetti MK \& Wells SA. Prophylactic thyroidectomy in multiple endocrine neoplasia type 2. New England Journal of Medicine 2005353 1105-1113.

7 Machens A, Niccoli-Sire P, Hoegel J, Frank-Raue K, van Vroonhoven TJ, Roeher HD, Wahl R, Lamesch P, Raue F, ConteDevolx B \& Dralle H. for the European Multiple Endocrine neoplasia (EUROMEN) Study Group. Early malignant progression of hereditary medullary thyroid cancer. New England Journal of Medicine 2003349 1517-1525.

8 Machens A, Gimm O, Hinze R, Höppner W, Boehm E \& Dralle H. Genotype-phenotype correlations in hereditary medullary thyroid carcinoma: oncological features and biochemical properties. Journal of Clinical Endocrinology and Metabolism 200186 1104-1109.

9 Brandi ML, Gagel RF, Angeli A, Bilezikian JP, Beck-Peccoz P, Bordi C, Conte-Devolx B, Falchetti A, Gheri RG, Libroia A, Lips CJM, Lombardi G, Mannelli M, Pacini F, Ponder B, Raue F, Skogseid B, Tamburano G, Thakker R, Thompson NW, Tomassetti P, Tonelli F, Wells S \& Marx S. Guidelines for diagnosis and therapy of MEN Type 1 and 2. Journal of Clinical Endocrinology and Metabolism 200186 5658-5671.

10 Szinnai G, Meier C, Komminoth P \& Zumsteg UW. Review of multiple endocrine neoplasia Type $2 \mathrm{~A}$ in children: Therapeutic results of early thyroidectomy and prognostic value of codon analysis. Pediatrics 2003111 132-139.

11 Niccoli-Sire P, Murat A, Rohmer V, Gibelin H, Chabrier G, ConteDevolx B, Visset J, Ronceray J, Jaeck D, Henry JF, Proye C, Carnaille B \& Kraimps JL. When should thyroidectomy be performed in familial medullary thyroid carcinoma gene carriers with non-cysteine RET mutations? Surgery 2003134 1029-1036.

12 Gimm O, Ukkat J, Niederle B, Weber T, Thanh PN, Brauckhoff M, Niederle B \& Dralle H. Timing and extent of surgery in patients with familial medullary thyroid carcinoma/multiple endocrine neoplasia 2A-related RET mutations not affecting codon 634 . World Journal of Surgery 200428 1312-1316.

13 Kouvaraki MA, Shapiro SE, Perrier ND, Cote GJ, Gagel RF, Hoff AO, Sherman SI, Lee JE \& Evans DB. RET proto-oncogene: a review and update of genotype-phenotype correlations in hereditary medullary thyroid cancer and associated endocrine tumors. Thyroid 200515 531-544.

14 Frank-Raue K, Höppner W, Frilling A, Kotzerke J, Dralle H, Haase R, Mann K, Seif F, Kirchner R, Rendl J, Deckart HF, Ritter MM, Hampel R, Klempa J, Scholz GH, Raue F \& the German Medullary Thyroid Carcinoma Study Group. Mutations in the RET proto-oncogene in German MEN families: relation between genotype and phenotype. Journal of Clinical Endocrinology and Metabolism 199681 17801783.

15 Frank-Raue K, Heimbach C, Rondot S, Usadel KH, Meng W, Varma C, Fuchs-Hammoser R, Höppner W, Schulze E \& Raue F. Herediatäres medulläres Schilddrüsencarzinom -Genotyp Phänotyp Charakterisierung. Deutsche Medizinische Wochenschrift 2003128 1998-2002.

16 Machens A, Schneyer U, Holzhausen HJ, Dralle H \& Raue F. Emergence of medullarythyroid carcinoma in a family with Cys630Arg RET germline mutation. Surgery 2004136 10831087. 
17 Yip L, Cote GL, Shapiro SE, Ayers GD, Herzog CE, Sellin RV, Sherman SI, Gagel RF \& Evans DB. Multiple endocrine neoplasia type 2: evaluation of the genotype-phenotype relationship. Archives of Surgery $2003 \mathbf{1 3 8}$ 409-416.

18 Berndt I, Reuter M, Saller B, Frank-Raue K, Groth P, Grussendorf M, Raue F, Ritter MM \& Höppner W. A new hot spot for mutations in the RET proto-oncogene causing familialmedullary thyroid carcinoma and multiple endocrine neoplasia type 2A. Journal of Clinical Endocrinology and Metabolism 199883 770-774.

19 Frohnauer MK \& Decker R. Update on the MEN 2A c804 RET mutation: is prophylactic thyroidectomy indicated? Surgery 2000 128 1052-1057.

20 Baumgartner-Parzer SM, Lang R, Wagner L, Heinze G, Niederle B, Kaserer K, Waldhäusl W \& Vierhapper H. Polymorphisms in Exon 13 and 14 of the RET protooncogene: genetic modifiers of medullary thyroid carcinoma? Journal of Clinical Endocrinology and Metabolism $2005906232-6236$.

21 Robledo M, Gil L, Pollan M, Cebrian A, Ruiz S, Azanedo M, Benitez J, Menarguez J \& Rojas JM. Polymorphisms G691S/S904S of RET as genetic modifiers of MEN 2A. Cancer Research 200363 1814-1817.

22 Lesueur F, Cebrian A, Robledo M, Niccoli-Sire P, Svensson KA, Pinson S, Leyland J, Wittacker J, Pharoah PD \& Ponder BA.
Polymorphisms in RET and its coreceptors and ligands as genetic modifiers of multiple endocrine neoplasia type $2 \mathrm{~A}$. Cancer Research 200666 1177-1180.

23 Fernandez RM, Navarro E, Antinolo G, Ruiz-Ferrer M \& Borrego S. Evaluation of the role of RET polymorphisms/haplotypes as modifier loci for MEN 2 and analysis of the correlation with the type of RET mutation in a series of Spanish patients. International Journal of Molecular Medicine 200617 575-581.

24 Canaris GJ, Manowitz NR, Mayor G \& Ridgeway EC. The Colorado thyroid disease prevalence study. Archives of Internal Medicine 2000 $160526-534$

25 Meier C, Trittibach P, Guglielmetti M, Staub JJ \& Müller B. Serum thyroid stimulating hormone in assessment of severity of tissue hypothyroidism in patients with overt primary thyroid failure. Cross sectional survey. British Medical Journal $2003 \mathbf{3 2 6}$ 311-312.

Received 21 February 2006

Accepted 24 May 2006 